INTERNATIONAL JOURNAL OF MULTidisciplinARY RESEARCH AND ANALYSis

ISSN(print): 2643-9840, ISSN(online): 2643-9875

Volume 04 Issue 03 March 2021

DOI: 10.47191/ijmra/v4-i3-02, Impact Factor: 6.072

Page No.- 231-240

\title{
On The Features of Changes In Hearing And Cerebral Hemodynamics In Patients With Nasal Obstruction Curvature
}

\author{
Khasanov U.S. ${ }^{1}$, Khayitov O.R. ${ }^{2}$, Djuraev J.A. ${ }^{3}$ \\ ${ }^{1} \mathrm{Head}$ of the Department of Otolaryngology and Dentistry, Tashkent Medical Academy, Doctor of Medical Sciences \\ 2Otolaryngologist at the clinic "QOQON DUNYO JAVOHIRI" \\ ${ }^{3}$ Senior lecturer, PhD of the Otolaryngology and Dentistry, Tashkent Medical Academy
}

\begin{abstract}
This article presents the characteristics of changes in the hearing and cerebral hemadynamics of patients with deviation of the nasal septum. The deviation of the nasal septum occurs in the cartilaginous and bone regions, both separately and in both at the same time. Deformations can be of a different nature (bend, crest, spike) and localization. They are one and two-sided. Spines and ridges are more often localized at the junction of the quadrangular cartilage and the perpendicular plate, ploughshare, and the crest of the upper jaw ("growth zone"). Less often, the upper sections of the perpendicular plate and the rear section of the ploughshare are deformed. For traumatic deformities, characteristic bends with sharp angles. Often, after injury, the anterior edge of the quadrilateral cartilage is displaced in the form of its subluxation. The deformation of the cartilaginous part of the external nose in the patients under our supervision was due to the deviation of the nasal septum. There were no patients with deformity of the nose, who would have been indicated for surgical intervention on the cartilage of the external nose, in our group.
\end{abstract}

KEYWORDS: cerebral hemadynamics, deviation of the nasal septum, quadrangular cartilage, septoplasty.

\section{INTRODUCTION}

The nasal septum has an impact on the formation of normal air aerodynamics [1,2]. A change in the latter leads to the development of pathological processes in the mucous membrane of the nasal cavity and paranasal sinuses [3]. The leading role in the regulation of air distribution through the nose belongs to the nasal valve, the cavernous tissue of the turbinates and the nasal septum $[4,5,6,7]$. The deviation of the nasal septum affects the direction of both inhaled and exhaled air. Even a slight difference in the absorption of oxygen leads to an increasing respiratory deficiency and oxygen deficiency. With deformation of the nasal septum, normal breathing is absent for a long time (months and years), which causes chronic hypoxia, which has negative consequences during the growth and development of the body [8,9].

With deformation of the nasal septum, a violation of oxidative processes is observed, which leads to a change in metabolic processes. The acid-base balance changes towards acidosis. Children lag behind in development, there is anemia, leukocytosis [10], the sugar content increases and the calcium content in the blood decreases [11], the ESR level rises [12,13,14]. All this affects the state of the nervous system and the functions of the brain. Such children are asthenic, apathetic, cannot concentrate, their memory deteriorates [15]. Disruption of nasal breathing at night interferes with sleep, and can cause attacks of sleep apnea. Difficulty in nasal breathing negatively affects the tone of the cerebral vessels and the level of intracranial and intraocular pressure. Turning off nasal breathing leads to the expansion of the lymphatic vessels of the brain, since the lymphatic system of the nose is the main pathway for the outflow of cerebrospinal fluid from the cranial cavity. Clinically, this is manifested by a feeling of heaviness in the head, headache, sleep disturbances, impairment of memory and learning in children $[16,17]$.

There is a connection between the function of the hearing tube and impaired nasal breathing, namely, its violation leads to dysfunction of the hearing tube. After prompt restoration of nasal breathing, the function of the hearing tube is normalized, which is explained by a decrease in edema of the nasopharyngeal mucosa due to the restoration of normal lymph flow from the nasal mucosa $[18,19]$.

A deviated nasal septum can negatively affect hearing function. The ridges and spines of the nasal septum, touching the mucous membrane of the lateral wall of the nasal cavity, cause its irritation, which is often accompanied by edema and infiltration 
of the mucous membrane. These processes can spread to the lining of the hearing tube and lead to hearing loss. Violation of the patency of the hearing tube often contributes to the emergence of acute otitis media, tubo-otitis, and in some cases, secretory otitis media. However, despite numerous works devoted to the deviation of the nasal septum in patients, the determination of the state of hearing function in such patients according to the data of tonal audiometry in the conventional $(0.125-8 \mathrm{kHz}) \mathrm{frequency}$ range has been devoted to separate works [11], and works on the study of hearing function in the extended the frequency range $(9-16 \mathrm{kHz})$ was not found by us.

A.V. Strativa recommends surgical correction of nasal structures in the complex treatment of exudative otitis media.

According to the observations of G.S. Protasevich, even in patients with adhesive otitis media, economical resection of the nasal septum can improve hearing.

The aim of this work is to study the state of hearing and cerebral hemodynamics in patients with deviation of the nasal septum.

In accordance with the purpose of the study and to fulfill the assigned tasks, clinical studies were carried out in 80 patients with deviation of the nasal septum who were hospitalized in the ENT department of "QO'QON DUNYO JAVOHIRI" for 2017-2020. All patients underwent a comprehensive examination, including the collection of complaints, examination of the ENT organs, endoscopy of the nasal cavity and X-ray studies.

\section{EVALUATION OF RESULTS}

The results of the conducted studies indicate that when examining patients with pathology of the nasal cavity, primarily with deviation of the nasal septum, it is imperative to pay attention to the quantitative indicators of tympanometry, which will make it possible to identify in them certain changes in the middle ear system in the early stages and timely take adequate medical and preventive measures.

We did not find a statistically significant difference between the parameters of cerebral hemodynamics in patients with a deviation of the nasal septum of a physiological nature and traumatic origin. Based on this, it can be concluded that the main cause of cerebral hemodynamic disorders is not a history of nasal trauma, but difficulty in nasal breathing and reflex changes in the body caused by deformation of the nasal septum.

As a result of the studies, which revealed the presence of sound conduction disturbances in most patients with deviation of the nasal septum and impaired cerebral hemodynamics (increased vascular tone and obstruction of venous outflow in patients with deformity of the nasal septum, we came to the conclusion that it is advisable to conduct a study of cerebral hemodynamics and hearing function both in the conventional $(0.125-8 \mathrm{kHz})$ and, especially, in the extended $(9-16 \mathrm{kHz})$ frequency range and taking into account the data of rheoencephalography and audiometry as an additional criterion in determining the indications for septoplasty.

\section{RESULTS AND DISCUSSION}

Investigating the state of hearing function in the usual $(0.125-8 \mathrm{kHz})$ frequency range, it was found that hearing for tones by bone conduction in all patients with deviation of the nasal septum and in the control group is within the normal range ( $p>0.05)$, which indicates on the preservation of the function of sound perception (Fig. 1).

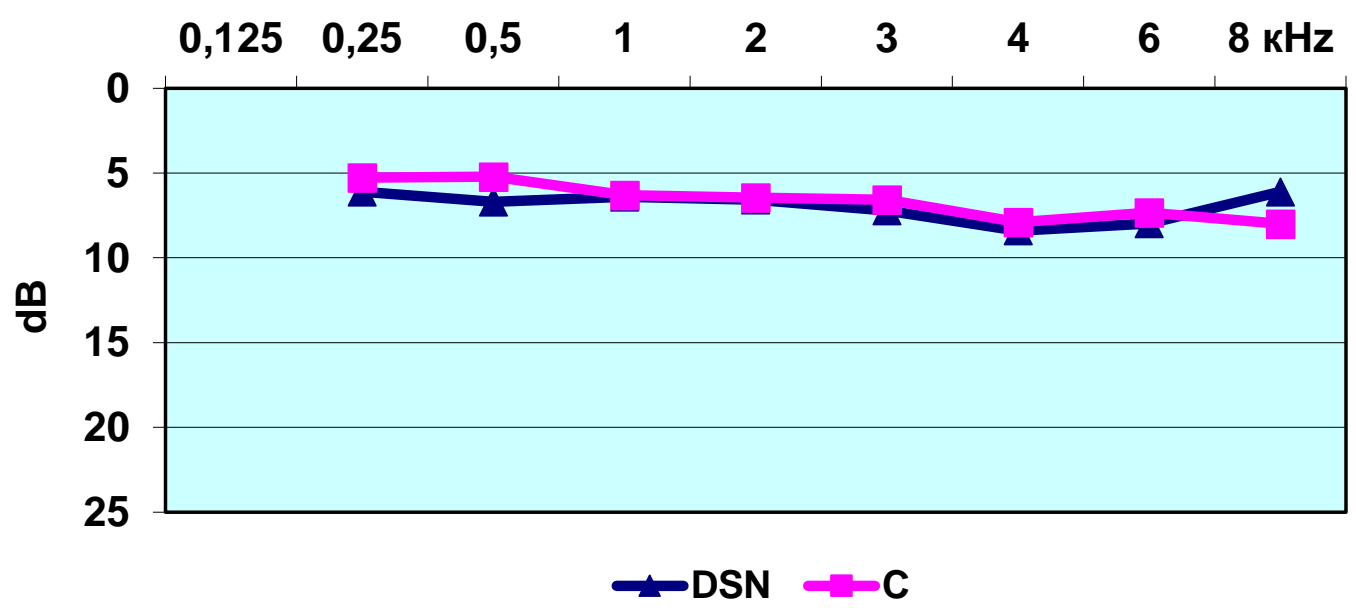

Figure: 1. Indices of perception of bone-conducted tones in the range of $0.125-8 \mathrm{kHz}$ in patients with nasal septum deviation (DSN) and in the control group (C). 
In $47(78.3 \%)$ patients studied by us with deviation of the nasal septum, there was a slight disturbance of sound conduction due to dysfunction of the hearing tube, as evidenced by the presence of an air-bone gap and a type $C$ tympanogram.

Table 1 shows indicators of conductive hearing impairment depending on the side of the deformation of the nasal septum. In most cases, the crest or spine of the nasal septum touched the inferior turbinate (grade III deformity). Only in 7 patients was the deviation of the nasal septum of II degree according to the classification of G.S. Protasevich.

Table 1

Distribution of the examined patients with deviation of the nasal septum, depending on the thresholds of air-conducted sounds in the usual frequency range on the side of deformity and in its absence ( $n$ is the number of ears)

\begin{tabular}{|c|c|c|c|c|c|}
\hline \multirow{4}{*}{$\begin{array}{l}\text { The side where the survey was } \\
\text { carried out }\end{array}$} & \multirow[t]{4}{*}{$\mathrm{n}$} & \multicolumn{4}{|c|}{ The side where the survey was carried out } \\
\hline & & $\begin{array}{l}\text { Within normal } \\
\text { limits }\end{array}$ & Enhanced & $\begin{array}{l}\text { Within normal } \\
\text { limits }\end{array}$ & Enhanced \\
\hline & & \multicolumn{4}{|c|}{ Number of observations } \\
\hline & & \multicolumn{2}{|l|}{ Abs. } & \multicolumn{2}{|l|}{$\%$} \\
\hline $\begin{array}{l}\text { With a deformation of the } \\
\text { nasal septum }\end{array}$ & 93 & 19 & 74 & 20,4 & 79,6 \\
\hline $\begin{array}{l}\text { Without deformation of the } \\
\text { nasal septum }\end{array}$ & 27 & 15 & 12 & 55,6 & 44,4 \\
\hline in conjunction & 120 & 34 & 86 & 28,3 & 71,7 \\
\hline
\end{tabular}

The table shows that in the usual frequency range, in the vast majority of cases (79.6\%), the observation sound is disturbed on the side of deviation of the nasal septum. Only in $20.4 \%$ of such patients are the thresholds of perception of airborne tones within the normal range. In $44.4 \%$ of the examined patients, it was significantly less pronounced. At the same time, in representatives $(55.6 \%)$ of patients, conducted with air - registered tones on the side of the deformation of the nasal septum, established within the normal range (Fig. 2).

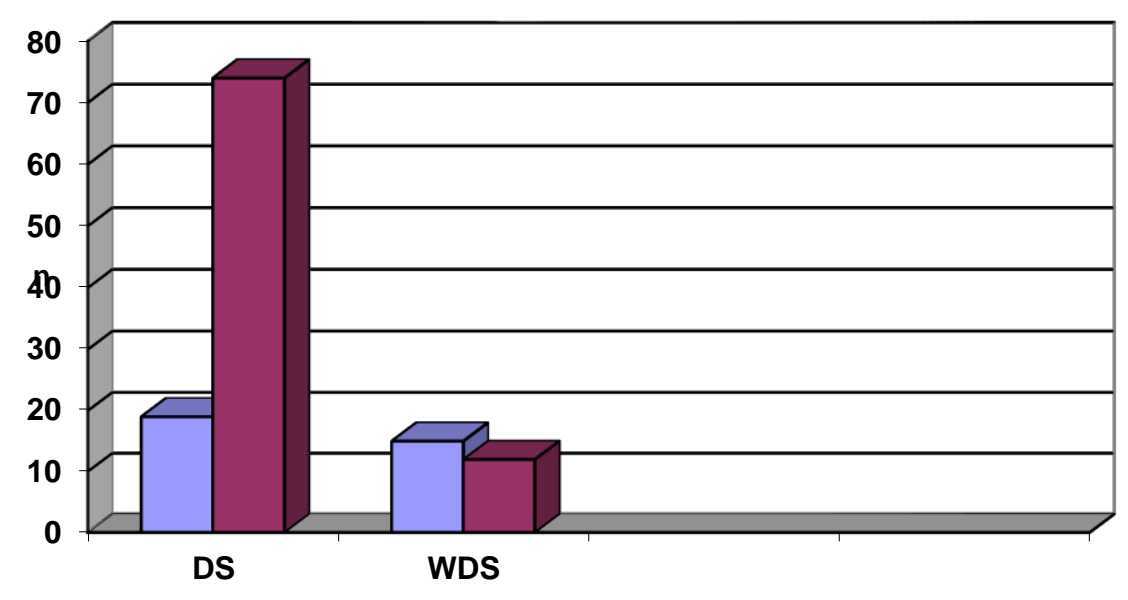

口within normal limits

口elevated

Figure: 2. Distribution of the examined patients with deviation of the nasal septum, depending on the thresholds of air conducted sounds in the usual frequency range on the side of deformity (DS) and without it (WDS) of the nasal septum ( $n$ the number of ears). 


\section{On The Features of Changes In Hearing And Cerebral Hemodynamics In Patients With Nasal Obstruction Curvature}

The results of tone audiometry for air conduction in the range of $0.125-8 \mathrm{kHz}$ are shown in Table 2.

\section{Table 2.}

Hearing thresholds for air - conducted tones in the usual frequency range in examined patients with deviation of the nasal septum (DNS), on the side of deformity (DS), on the opposite side of deformity (WDS) and in healthy control group (K)

\begin{tabular}{|c|c|c|c|c|c|c|c|c|c|}
\hline \multirow{3}{*}{$\begin{array}{l}\text { Groups of } \\
\text { examined } \\
\text { patients }\end{array}$} & \multicolumn{9}{|c|}{ Hearing thresholds for air-conducted tones $(\mathrm{dB})$ in the area } \\
\hline & $\begin{array}{l}0,125 \\
\mathrm{kHz}\end{array}$ & $0,25 \mathrm{kHz}$ & $0,5 \mathrm{kHz}$ & $1 \mathrm{kHz}$ & $2 \mathrm{kHz}$ & $3 \mathrm{kHz}$ & $4 \mathrm{kHz}$ & $6 \mathrm{kHz}$ & $8 \mathrm{kHz}$ \\
\hline & \multicolumn{9}{|l|}{$\mathrm{M} \pm \mathrm{m}$} \\
\hline K & $\begin{array}{l}5,28 \pm \\
0,32\end{array}$ & $\begin{array}{l}5,21 \pm \\
0,43\end{array}$ & $\begin{array}{l}6,31 \pm \\
0,56\end{array}$ & $\begin{array}{l}6,45 \pm \\
0,48\end{array}$ & $\begin{array}{l}6,56 \pm \\
0,56\end{array}$ & $\begin{array}{l}7,89 \pm \\
0,76\end{array}$ & $\begin{array}{l}7,34 \pm \\
0,67\end{array}$ & $\begin{array}{l}7,51 \pm \\
0,98\end{array}$ & $\begin{array}{l}7,99 \pm \\
0,76\end{array}$ \\
\hline DNS & $\begin{array}{l}14,96 \pm \\
0,68\end{array}$ & $\begin{array}{l}16,61 \pm \\
0,96\end{array}$ & $\begin{array}{l}14,91 \pm \\
0,87\end{array}$ & $\begin{array}{l}14,01 \pm \\
0,92\end{array}$ & $\begin{array}{l}13,19 \pm \\
0,99\end{array}$ & $\begin{array}{l}13,68 \pm \\
0,92\end{array}$ & $\begin{array}{l}14,48 \\
\pm 1,03\end{array}$ & $\begin{array}{l}19,14 \\
\pm 1,15\end{array}$ & $\begin{array}{l}16,77 \\
\pm 1,09\end{array}$ \\
\hline DS & $\begin{array}{l}16,85 \pm \\
1,14\end{array}$ & $\begin{array}{l}17,82 \pm \\
1,07\end{array}$ & $\begin{array}{l}18,44 \\
\pm 1,22\end{array}$ & $\begin{array}{l}19,55 \\
\pm 1,48\end{array}$ & $\begin{array}{l}18,91 \\
\pm 1,23\end{array}$ & $\begin{array}{l}20,44 \\
\pm 1,16\end{array}$ & $\begin{array}{l}19,88 \\
\pm 1,12\end{array}$ & $\begin{array}{l}23,21 \pm 1 \\
, 15\end{array}$ & $\begin{array}{l}20,15 \pm \\
1,48\end{array}$ \\
\hline WDS & $\begin{array}{l}10,45 \pm \\
0,98\end{array}$ & $\begin{array}{l}12,82 \pm \\
1,09\end{array}$ & $\begin{array}{l}13,36 \\
\pm 0,94\end{array}$ & $\begin{array}{l}13,84 \pm \\
1,18\end{array}$ & $\begin{array}{l}12,81 \pm \\
1,08\end{array}$ & $\begin{array}{l}13,69 \pm \\
1,03\end{array}$ & $\begin{array}{l}14,58 \pm \\
1,06\end{array}$ & $\begin{array}{l}15,41 \pm 1 \\
, 12\end{array}$ & $\begin{array}{l}14,12 \pm \\
1,11\end{array}$ \\
\hline $\mathrm{t} / \mathrm{p}$ (K-DNS) & $\begin{array}{l}12,87 \\
<0,001\end{array}$ & $\begin{array}{l}10,84 \\
<0,001\end{array}$ & $\begin{array}{l}7,99 \\
<0,001\end{array}$ & $\begin{array}{l}7,28 \\
<0,001\end{array}$ & $\begin{array}{l}5,83 \\
<0,001\end{array}$ & $\begin{array}{l}4,85 \\
<0,001\end{array}$ & $\begin{array}{l}5,81 \\
<0,001\end{array}$ & $\begin{array}{l}7,70 \\
<0,001\end{array}$ & $\begin{array}{l}6,61 \\
<0,001\end{array}$ \\
\hline$t / p(K-D S)$ & $\begin{array}{l}9,78 \\
<0,001\end{array}$ & $\begin{array}{l}10,94 \\
<0,001\end{array}$ & $\begin{array}{l}9,04 \\
<0,001\end{array}$ & $\begin{array}{l}8,41 \\
<0,001\end{array}$ & $\begin{array}{l}9,13 \\
<0,001\end{array}$ & $\begin{array}{l}9,05 \\
<0,001\end{array}$ & $\begin{array}{l}9,61 \\
<0,001\end{array}$ & $\begin{array}{l}10,39 \\
<0,001\end{array}$ & $\begin{array}{l}7,31 \\
<0,001\end{array}$ \\
\hline $\mathrm{t} / \mathrm{p}(\mathrm{K}-\mathrm{WDS})$ & $\begin{array}{l}5,01 \\
<0,001\end{array}$ & $\begin{array}{l}6,49 \\
<0,001\end{array}$ & $\begin{array}{l}6,44 \\
<0,001\end{array}$ & $\begin{array}{l}5,80 \\
<0,001\end{array}$ & $\begin{array}{l}5,14 \\
<0,001\end{array}$ & $\begin{array}{l}4,53 \\
<0,001\end{array}$ & $\begin{array}{l}5,77 \\
<0,001\end{array}$ & $\begin{array}{l}5,31 \\
<0,001\end{array}$ & $\begin{array}{l}4,56 \\
<0,001\end{array}$ \\
\hline$t / p(D S-W D S)$ & $\begin{array}{l}4,26 \\
<0,001\end{array}$ & $\begin{array}{l}3,27 \\
<0,01\end{array}$ & $\begin{array}{l}3,29 \\
<0,01\end{array}$ & $\begin{array}{l}3,03 \\
<0,01\end{array}$ & $\begin{array}{l}3,72 \\
<0,001\end{array}$ & $\begin{array}{l}4,35 \\
<0,001\end{array}$ & $\begin{array}{l}3,43 \\
<0,01\end{array}$ & $\begin{array}{l}4,85 \\
<0,001\end{array}$ & $\begin{array}{l}3,26 \\
<0,01\end{array}$ \\
\hline
\end{tabular}

Table 2 shows that in patients with deviation of the nasal septum (DNS), the hearing thresholds for air-conducted tones are statistically significantly increased at all studied frequencies $(p<0.001)$ in comparison with the control group. This difference turned out to be somewhat more pronounced when comparing these indicators of the control group and patients with deviation of the nasal septum on the side of deformity (DM), compared with the side without deformation (WDS) of the nasal septum. When comparing the thresholds of perception of air - conducted tones in the frequency range $0.125-8 \mathrm{kHz}$ on the side of deformation and without deformation, a statistically significant difference was also revealed $(p<0.01)$.

Thus, in patients with deviation of the nasal septum, there is a decrease in conductive hearing in the usual frequency ranges $(0.125-8 \mathrm{kHz})$ in $78.3 \%$, and in the extended $(9-16 \mathrm{kHz})-$ in $95 \%$. The hearing loss is mostly on the side of the deviation of the nasal septum. On the side without deformation of the nasal septum, the impairment of hearing function by the type of sound conduction was less pronounced, or the hearing function was within normal limits.

We performed acoustic impedance measurements in 60 patients with deviation of the nasal septum. Since in some cases we received asymmetric tympanograms, the percentage calculations were performed not for the number of people, but for the number of ears.

Analysis of the results of the study showed the following: tympanograms of type "A" (different subtypes) had 40 people ( 80 ears), that is, $66.7 \%$, in 8 people (12 ears), or in $10.0 \%$ of cases, a tympanogram of type "B ", In 12 people and in 4 on one side (28 ears) - in $23.3 \%$ we registered a type C tympanogram (Fig. 3 ). 


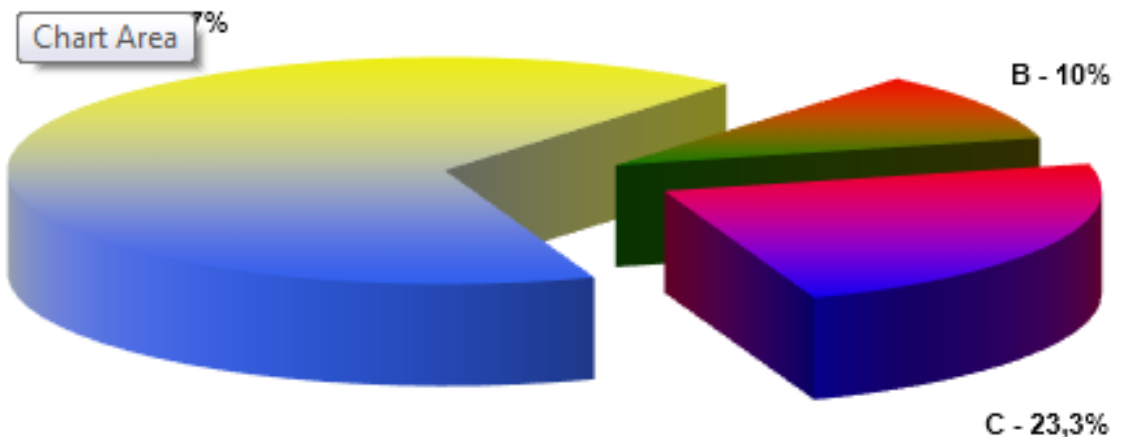

Figure: 3. Distribution of patients with a deviation of the nasal septum by the tympanogram type.

As a rule, all type $C$ tympanograms were recorded in the studied patients on the side of the nasal septum deformity. It should be noted that ARVM was caused in almost all cases, with the exception of patients with type B tympanogram.

It should also be noted that among patients with a type "A" tympanogram, only 17 patients (21.3\%) had a common type "A" tympanogram. As a rule, it was registered from the side of the opposite deformation of the nasal septum. In 34 patients (42.5\%) there was a tympanogram of the "Al" type with a shift of the apex in the negative direction from -20 to -50 hia, and in 29 cases (36.2\%), a tympanogram of the " $A$ *" type was recorded with a reduced compliance, but values of intratympanic pressure from +20 to -20 gna (Fig. 4).

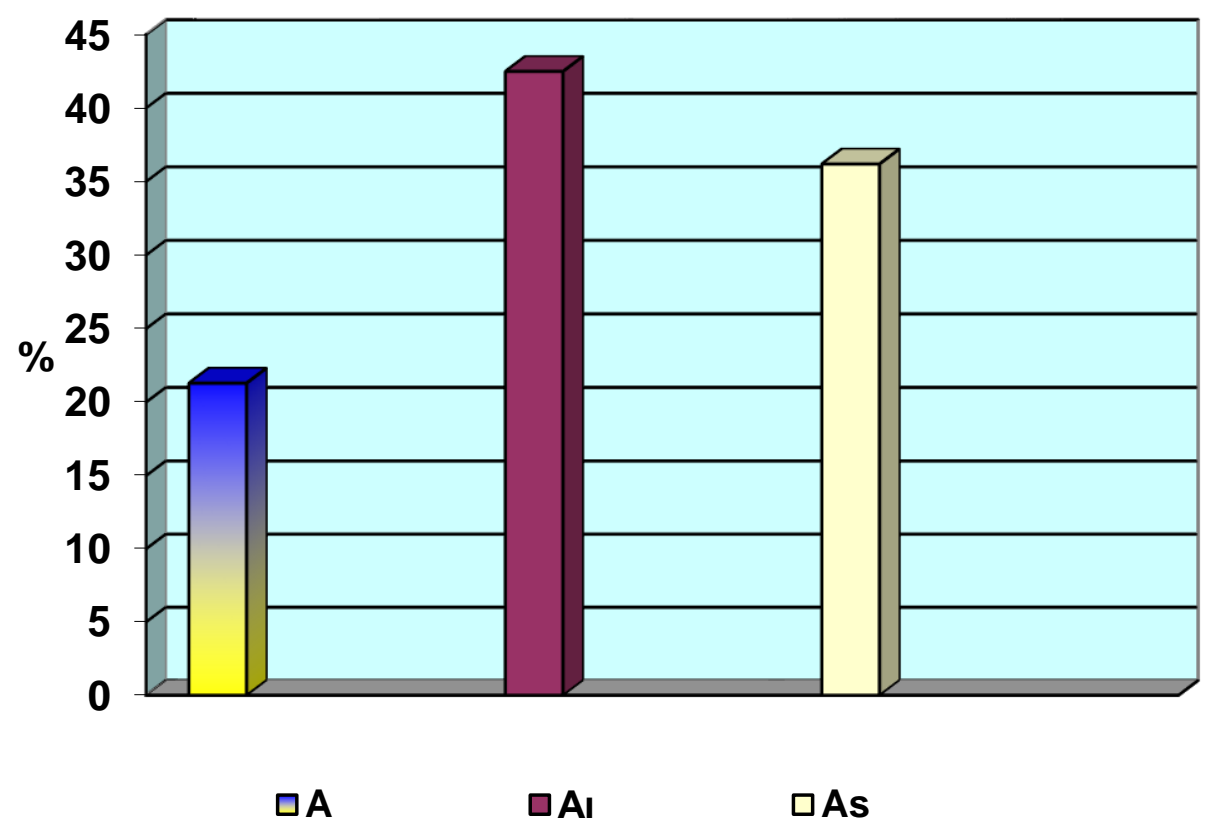

Figure: 4. Distribution of patients with deviation of the nasal septum, depending on the type A tympanogram variants.

So, according to the type of tympanogram, the patients were divided into 5 groups. Table 4 presents a comparative analysis of the mean compliance values in 4 subgroups of patients and the control group. Patients from subgroup " $\mathrm{B}$ " were not taken by us before analysis.

\section{Table 4.}

Compliance value in healthy people and with deviation of the nasal septum, depending on the type of tympanogram registered in them and the range of intratympanic pressure

\begin{tabular}{|l|l|l|}
\hline Groups of examined & $\begin{array}{l}\text { Compliance value, } \\
\mathrm{cm}^{3}(\mathrm{M} \pm \mathrm{m})\end{array}$ & Intratympanic pressure range, $\mathrm{dPa}$ \\
\hline $\mathrm{A}(\mathrm{n}=17)$ & $0,73 \pm 0,06$ & $-20+18$ \\
\hline $\mathrm{Al}(\mathrm{n}=34)$ & $0,41 \pm 0,08$ & $-50-21$ \\
\hline
\end{tabular}


On The Features of Changes In Hearing And Cerebral Hemodynamics In Patients With Nasal Obstruction Curvature

\begin{tabular}{|l|l|l|}
\hline As $(n=29)$ & $0,32 \pm 0,07$ & $-20+19$ \\
\hline$C(n=28)$ & $0,44 \pm 0,09$ & $-108-50$ \\
\hline$K(n=20)$ & $0,91 \pm 0,04$ & $-12+17$ \\
\hline$t / p(A-K)$ & $2,50(p<0,05)$ & \\
\hline$t / p(A I-K)$ & $3,95(p<0,01)$ & \\
\hline$t / p(A s-K)$ & $7,32(p<0,01)$ & \\
\hline$t / p(C-K)$ & $4,77(p<0,01)$ & \\
\hline
\end{tabular}

From the presented table 4 it can be seen that in all groups of the studied patients there is a significant decrease in the value of compliance compared with the control group. This also applies to patients with a deviation of the nasal septum, in which tympanograms of type A were recorded. Thus, the compliance in the studied patients with deviation of the nasal septum, in which tympanograms of type A were recorded $0.73 \pm 0.06 \mathrm{~cm} 3$, and in the control group of healthy people $-0.91 \pm 0.04 \mathrm{~cm} 3 ; t=2.5 ; p$ $<0.05$, that is, a significant difference was found in these indicators.

An even greater and more significant $(p<0.01)$ difference was found in the compliance indicators of patients with nasal septum deviation, in whom type $A$ 'tympanograms were registered; $A$ and $C$, in which the compliance value was respectively: $0.41 \pm 0.08 ; 0.32 \pm 0.07$ and $0.44 \pm 0.09 \mathrm{~cm} 3$.

The difference is also determined in the ranges of intratympanic pressure in the indicated groups of studied patients with deviation of the nasal septum in comparison with healthy people.

As for the threshold values of ARVM, their significant $(p<0.01 ; p<0.05)$ increase in comparison with the control occurred only in the subgroup of children with " $\mathrm{C}$ " tympanograms during ipsi and contralateral stimulation at frequencies of $0.5,1$ and 2 $\mathrm{kHz}$. A comparative analysis of the threshold values of ARVM in the surveyed groups is shown in Table 5.

The study showed that according to the data of acoustic impedance measurement in patients with a deviation of the nasal septum, changes in the sound underwater system of the hearing analyzer are revealed. Such violations, of course, is evidenced by the presence of tympanograms of type "B" and "C" in such patients. But you should pay attention to the fact that although the majority of the examined patients have several types of tympanograms of type "A", their compliance indicators significantly $(p<0.01)$ differ from the data of the control group. So, it should also be emphasized that in patients without clinical signs of tubo-otitis, changes are already recorded in the conduction system of the hearing analyzer according to the data of dynamic tympanometry.

Table 5.

The value of ARVM in healthy people and with a deviation of the nasal septum, depending on the type of tympanogram registered in them

\begin{tabular}{|c|c|c|c|c|c|c|}
\hline \multirow{4}{*}{ Groups } & \multicolumn{6}{|c|}{ Threshold indicators of ARVM, dB } \\
\hline & \multicolumn{3}{|c|}{ Ipsilateral stimulation } & \multicolumn{3}{|c|}{ Contralateral stimulation } \\
\hline & $0,5 \mathrm{kHz}$ & $1 \mathrm{kHz}$ & $2 \mathrm{kHz}$ & $0,5 \mathrm{kHz}$ & $1 \mathrm{kHz}$ & $2 \mathrm{kHz}$ \\
\hline & \multicolumn{6}{|l|}{$\mathrm{M} \pm \mathrm{m}$} \\
\hline$A(n=17)$ & $87,84 \pm 2,36$ & $84,21 \pm 3,65$ & $87,55 \pm 4,21$ & $86,39 \pm 3,14$ & $87,65 \pm 4,28$ & $88,68 \pm 5,24$ \\
\hline AI $(n=34)$ & $86,22 \pm 5,12$ & $84,36 \pm 3,44$ & $88,45 \pm 5,32$ & $86,56 \pm 5,36$ & $88,21 \pm 5,38$ & $87,46 \pm 3,64$ \\
\hline As $(n=29)$ & $85,29 \pm 2,69$ & $85,78 \pm 5,21$ & $85,41 \pm 4,36$ & $86,11 \pm 3,55$ & $87,22 \pm 4,65$ & $88,16 \pm 5,33$ \\
\hline$C(n=28)$ & $95,22 \pm 2,21$ & $94,33 \pm 2,56$ & $96,28 \pm 2,65$ & $97,51 \pm 3,12$ & $96,88 \pm 3,41$ & $98,14 \pm 2,55$ \\
\hline$K(n=20)$ & $85,21 \pm 2,31$ & $85,98 \pm 2,42$ & $87,08 \pm 3,53$ & $85,52 \pm 3,98$ & $86,98 \pm 3,36$ & $86,97 \pm 3,02$ \\
\hline$t / p(A-K)$ & $\begin{array}{l}0,80 \\
(p>0,05)\end{array}$ & $\begin{array}{l}0,40 \\
(p>0,05)\end{array}$ & $\begin{array}{l}0,09 \\
(p>0,05)\end{array}$ & $\begin{array}{l}0,17 \\
(p>0,05)\end{array}$ & $\begin{array}{l}0,12 \\
(p>0,05)\end{array}$ & $\begin{array}{l}0,28 \\
(p>0,05)\end{array}$ \\
\hline
\end{tabular}


On The Features of Changes In Hearing And Cerebral Hemodynamics In Patients With Nasal Obstruction Curvature

\begin{tabular}{|l|l|l|l|l|l|l|}
\hline$t / p(A I-K)$ & $\begin{array}{l}0,18 \\
(p>0,05)\end{array}$ & $\begin{array}{l}0,39 \\
(p>0,05)\end{array}$ & $\begin{array}{l}0,21 \\
(p>0,05)\end{array}$ & $\begin{array}{l}0,16 \\
(p>0,05)\end{array}$ & $\begin{array}{l}0,19 \\
(p>0,05)\end{array}$ & $\begin{array}{l}0,12 \\
(p>0,05)\end{array}$ \\
\hline$t / p(A s-K)$ & 0,02 & 0,03 & 0,30 & 0,11 & 0,04 & 0,19 \\
$(p>0,05)$ & $(p>0,05)$ & $(p>0,05)$ & $(p>0,05)$ & $(p>0,05)$ & $(p>0,05)$ \\
\hline$t / p(C-K)$ & 3,13 & 2,37 & 2,08 & 2,37 & 2,07 & 2,83 \\
$(p<0,01)$ & $(p<0,05)$ & $(p<0,05)$ & $(p<0,05)$ & $(p<0,05)$ & $(0,05)$ \\
\hline
\end{tabular}

\section{Cerebral hemodynamics in patients with nasal septum deviation before surgery}

A qualitative assessment revealed that before the operation, an increase in the tone of cerebral vessels and obstruction of venous outflow in the carotid system in groups 1 and 2 of patients with a deviation of the nasal septum occurs in all studied patients. Cerebral vasospasm was not observed. Almost similar data on the results of REG are observed in the vertebrobasilar system. A decrease in pulse blood filling, respectively, was not observed in both the carotid and vertebrobasilar systems.

The quantitative REG indices in the carotid system in patients with nasal septum deviation of groups 1 and 2 and in the control group are shown in Table 3, and the REG indices in the basin of the vertebrobasilar system and in the control group are shown in Table 6.

Table 6.

Quantitative indicators of REG in FM lead in the studied patients with physiological and traumatic deviation of the nasal septum (groups 1 and 2, respectively) and in the control group

\begin{tabular}{|c|c|c|c|c|c|c|c|c|}
\hline \multirow{3}{*}{$\begin{array}{r}\text { REG } \\
\text { indicators }\end{array}$} & \multirow{3}{*}{$\begin{array}{l}\text { Od. } \\
\text { Measure } \\
\text { ments }\end{array}$} & \multirow{3}{*}{$\begin{array}{l}\text { Side } \\
\text { R- } \\
\text { rights } \\
\text { L-left }\end{array}$} & \multicolumn{3}{|c|}{ REG quantitative indicators } & \multicolumn{3}{|l|}{$\mathrm{t}$} \\
\hline & & & $\begin{array}{l}1 \text { group } \\
(n=42)\end{array}$ & $\begin{array}{l}2 \text { group } \\
(n=18)\end{array}$ & $\begin{array}{l}\text { Control } \\
\text { group } \\
(n=20)\end{array}$ & I-K & II-K & $|-I|$ \\
\hline & & & \multicolumn{3}{|l|}{$\mathrm{M} \pm \mathrm{m}$} & & & \\
\hline$T$ & c & $\begin{array}{l}R \\
L\end{array}$ & $\begin{array}{l}0,62 \pm 0,02 \\
0,60 \pm 0,03\end{array}$ & $\begin{array}{l}0,61 \pm 0,02 \\
0,59 \pm 0,03\end{array}$ & $\begin{array}{l}0,58 \pm 0,001 \\
0,58 \pm 0,001\end{array}$ & $\begin{array}{l}2,0 \\
0,67\end{array}$ & $\begin{array}{l}1,50 \\
0,34\end{array}$ & $\begin{array}{l}0,35 \\
0,24\end{array}$ \\
\hline$\alpha$ & c & $\begin{array}{l}\mathrm{R} \\
\mathrm{L}\end{array}$ & $\begin{array}{l}0,12 \pm 0,001 \\
0,11 \pm 0,001\end{array}$ & $\begin{array}{l}0,11 \pm 0,001 \\
0,12 \pm 0,001\end{array}$ & $\begin{array}{l}0,102 \pm 0,001 \\
0,102 \pm 0,001\end{array}$ & $\begin{array}{l}12,73 \\
5,66\end{array}$ & $\begin{array}{l}5,66 \\
12,73\end{array}$ & $\begin{array}{l}7,07 \\
7,07\end{array}$ \\
\hline$\beta$ & c & $\begin{array}{l}\mathrm{R} \\
\mathrm{L}\end{array}$ & $\begin{array}{l}0,51 \pm 0,01 \\
0,52 \pm 0,01\end{array}$ & $\begin{array}{l}0,52 \pm 0,01 \\
0,54 \pm 0,01\end{array}$ & $\begin{array}{l}0,48 \pm 0,02 \\
0,48 \pm 0,02\end{array}$ & $\begin{array}{l}1,34 \\
2,24\end{array}$ & $\begin{array}{l}1,79 \\
2,68\end{array}$ & $\begin{array}{l}0,71 \\
0,71\end{array}$ \\
\hline$\alpha / T$ & $\%$ & $\begin{array}{l}\mathrm{R} \\
\mathrm{L}\end{array}$ & $\begin{array}{l}0,26 \pm 0,01 \\
0,28 \pm 0,01\end{array}$ & $\begin{array}{l}0,27 \pm 0,01 \\
0,29 \pm 0,01\end{array}$ & $\begin{array}{l}0,19 \pm 0,01 \\
0,19 \pm 0,01\end{array}$ & $\begin{array}{l}4,95 \\
6,36\end{array}$ & $\begin{array}{l}5,66 \\
7,07\end{array}$ & $\begin{array}{l}0,71 \\
0,71\end{array}$ \\
\hline $\mathrm{PI}$ & fr. & $\begin{array}{l}R \\
L\end{array}$ & $\begin{array}{l}1,15 \pm 0,03 \\
1,17 \pm 0,02\end{array}$ & $\begin{array}{l}1,08 \pm 0,03 \\
1,12 \pm 0,02\end{array}$ & $\begin{array}{l}1,2 \pm 0,03 \\
1,2 \pm 0,03\end{array}$ & $\begin{array}{l}1,89 \\
1,11\end{array}$ & $\begin{array}{l}3,06 \\
2,49\end{array}$ & $\begin{array}{l}1,18 \\
1,77\end{array}$ \\
\hline DKI & $\%$ & $\begin{array}{l}\mathrm{R} \\
\mathrm{L}\end{array}$ & $\begin{array}{l}61,25 \pm 1,47 \\
68,48 \pm 2,14 \\
\end{array}$ & $\begin{array}{l}62,47 \pm 2,08 \\
67,24 \pm 1,98 \\
\end{array}$ & $\begin{array}{l}51,40 \pm 2,6 \\
51,40 \pm 2,6\end{array}$ & $\begin{array}{l}3,3 \\
5,07 \\
\end{array}$ & $\begin{array}{l}3,33 \\
4,85 \\
\end{array}$ & $\begin{array}{l}0,48 \\
0,43\end{array}$ \\
\hline $\mathrm{DCl}$ & $\%$ & $\begin{array}{l}R \\
L\end{array}$ & $\begin{array}{l}68,11 \pm 1,64 \\
71,23 \pm 2,32\end{array}$ & $\begin{array}{l}70,38 \pm 2,04 \\
76,37 \pm 2,12\end{array}$ & $\begin{array}{l}59,3 \pm 2,8 \\
59,3 \pm 2,8\end{array}$ & $\begin{array}{l}2,72 \\
3,28\end{array}$ & $\begin{array}{l}3,2 \\
4,86\end{array}$ & $\begin{array}{l}0,87 \\
1,64\end{array}$ \\
\hline
\end{tabular}

The table shows that in patients of group 1, that is, with physiological deviation of the nasal septum, compared with the control group, a statistically significant $(p<0.01)$ lengthening of the anacrotic $(\alpha)$ phase of the REG curve is observed. So, the case in the indicated patients was $(0.12 \pm 0.001) \mathrm{s}$, and in the control group $-(0.102 \pm 0.001) \mathrm{s}(\mathrm{t}=12.73 ; \mathrm{p}<0.001)$. This indicates the presence of an increased tone of cerebral vessels in these patients.

An increase in the tone of cerebral vessels in patients of group 1 is also confirmed by the indicators of the dicrotic index (DIC). Yes, the case in patients with nasal septum deviation in group 1 DIC was $(61.25 \pm 1.47) \%$, and in the control group - (51.4 \pm $2.6) \%(t=3.3 ; p<0,01)$, on the left this difference was even more pronounced $(t=5.07 ; p<0.001)$. 


\section{On The Features of Changes In Hearing And Cerebral Hemodynamics In Patients With Nasal Obstruction Curvature}

Patients with nasal septum deviation of group 1 also had obstruction of venous outflow in the carotid system. This is evidenced by the indicators of the diastolic index (DSI). So, until now, in patients of group 1 , the case was $68.11 \pm 1.64 \%$, and in the control group $-59.3 \pm 2.8 \%(t=2.72 ; p<0.05)$. Similar disorders in the vessels of the brain were found in the carotid system in the examined patients of group 1 in the left hemisphere.

Regarding pulse blood filling, it was within the normal range in both groups of patients, as evidenced by the normal values of the rheographic index (RI).

\section{Table 7.}

Quantitative indicators of REG in OM lead in the studied patients with physiological and traumatic deviation of the nasal septum (groups 1 and 2, respectively) and in the control group

\begin{tabular}{|c|c|c|c|c|c|c|c|c|}
\hline \multirow{3}{*}{$\begin{array}{r}\text { REG } \\
\text { indicators }\end{array}$} & \multirow{3}{*}{$\begin{array}{l}\text { Od. } \\
\text { Measure } \\
\text { ments }\end{array}$} & \multirow{3}{*}{$\begin{array}{l}\text { Side } \\
\text { R- } \\
\text { rights } \\
\text { R- } \\
\text { right }\end{array}$} & \multicolumn{3}{|c|}{ REG quantitative indicators } & \multicolumn{3}{|l|}{$\mathrm{t}$} \\
\hline & & & $\begin{array}{l}1 \text { group } \\
(n=42)\end{array}$ & $\begin{array}{l}2 \text { group } \\
(n=18)\end{array}$ & $\begin{array}{l}\text { Control } \\
\text { group }(n=20)\end{array}$ & $\mathrm{I}-\mathrm{K}$ & II-K & $\mid-I I$ \\
\hline & & & \multicolumn{3}{|l|}{$M \pm m$} & & & \\
\hline$T$ & $\mathrm{C}$ & $\begin{array}{l}R \\
L\end{array}$ & $\begin{array}{l}0,66 \pm 0,03 \\
0,63 \pm 0,03\end{array}$ & $\begin{array}{l}0,68 \pm 0,02 \\
0,61 \pm 0,02\end{array}$ & $\begin{array}{l}0,58 \pm 0,001 \\
0,58 \pm 0,001\end{array}$ & $\begin{array}{l}2,67 \\
1,67\end{array}$ & $\begin{array}{l}4,99 \\
1,5\end{array}$ & $\begin{array}{l}0,55 \\
0,55\end{array}$ \\
\hline$\alpha$ & c & $\begin{array}{l}\mathrm{R} \\
\mathrm{L}\end{array}$ & $\begin{array}{l}0,12 \pm 0,001 \\
0,13 \pm 0,001\end{array}$ & $\begin{array}{l}0,12 \pm 0,001 \\
0,14 \pm 0,001\end{array}$ & $\begin{array}{l}0,102 \pm 0,001 \\
0,102 \pm 0,001\end{array}$ & $\begin{array}{l}12,73 \\
19,8\end{array}$ & $\begin{array}{l}12,73 \\
26,87\end{array}$ & $\begin{array}{l}0 \\
0\end{array}$ \\
\hline$\beta$ & $\mathrm{C}$ & $\begin{array}{l}\mathrm{R} \\
\mathrm{L}\end{array}$ & $\begin{array}{l}0,52 \pm 0,01 \\
0,54 \pm 0,01\end{array}$ & $\begin{array}{l}0,55 \pm 0,01 \\
0,57 \pm 0,01\end{array}$ & $\begin{array}{l}0,48 \pm 0,02 \\
0,48 \pm 0,02\end{array}$ & $\begin{array}{l}1,79 \\
2,68\end{array}$ & $\begin{array}{l}3,13 \\
4,02\end{array}$ & $\begin{array}{l}2,12 \\
2,12\end{array}$ \\
\hline$\alpha / T$ & $\%$ & $\begin{array}{l}R \\
L\end{array}$ & $\begin{array}{l}0,29 \pm 0,01 \\
0,28 \pm 0,01\end{array}$ & $\begin{array}{l}0,28 \pm 0,01 \\
0,31 \pm 0,01\end{array}$ & $\begin{array}{l}0,19 \pm 0,01 \\
0,19 \pm 0,01\end{array}$ & $\begin{array}{l}7,07 \\
6,36\end{array}$ & $\begin{array}{l}6,36 \\
8,49\end{array}$ & $\begin{array}{l}0,71 \\
2,12\end{array}$ \\
\hline $\mathrm{PI}$ & Fr. & $\begin{array}{l}\mathrm{R} \\
\mathrm{L}\end{array}$ & $\begin{array}{l}1,03 \pm 0,02 \\
1,04 \pm 0,03\end{array}$ & $\begin{array}{l}1,01 \pm 0,02 \\
1,06 \pm 0,02\end{array}$ & $\begin{array}{l}1,21 \pm 0,03 \\
1,21 \pm 0,03\end{array}$ & $\begin{array}{l}4,99 \\
4,01\end{array}$ & $\begin{array}{l}5,55 \\
4,16\end{array}$ & $\begin{array}{l}0,71 \\
0,55\end{array}$ \\
\hline DKI & $\%$ & $\begin{array}{l}R \\
L\end{array}$ & $\begin{array}{l}68,35 \pm 2,17 \\
71,29 \pm 2,21\end{array}$ & $\begin{array}{l}72,91 \pm 1,96 \\
74,15 \pm 2,12\end{array}$ & $\begin{array}{l}51,40 \pm 2,6 \\
51,40 \pm 2,6\end{array}$ & $\begin{array}{l}5,01 \\
5,83\end{array}$ & $\begin{array}{l}6,61 \\
6,78\end{array}$ & $\begin{array}{l}1,56 \\
0,93\end{array}$ \\
\hline $\mathrm{DCl}$ & $\%$ & $\begin{array}{l}R \\
L\end{array}$ & $\begin{array}{l}72,35 \pm 2,31 \\
76,41 \pm 2,15\end{array}$ & $\begin{array}{l}69,98 \pm 2,18 \\
72,24 \pm 2,19\end{array}$ & $\begin{array}{l}59,3 \pm 2,8 \\
59,3 \pm 2,8\end{array}$ & $\begin{array}{l}3,6 \\
4,85\end{array}$ & $\begin{array}{l}3,01 \\
3,64\end{array}$ & $\begin{array}{l}0,75 \\
1,36\end{array}$ \\
\hline
\end{tabular}

The state of cerebral vessels in the vertebrobasilar basin (Table 7) in patients with physiological and traumatic deviation of the nasal septum (groups 1 and 2, respectively) practically did not differ from the state of the vessels of the carotid system.

There was no significant difference $(p>0.05)$ in these indicators in patients with nasal septum deviation of groups 1 and 2.

So, our studies have shown that the state of the cerebral vessels according to the REG results in patients with nasal septum deviation significantly differs from the control group without nasal septum deviation both in FM and OM leads. Moreover, in patients of both groups, in comparison with the control, there is an increase in the vascular tone of the brain and difficulty in venous outflow.

We did not find a statistically significant difference between the indicators of cerebral hemodynamics in patients with a deviation of the nasal septum of a physiological nature and a traumatic origin. Based on this, it can be concluded that the main cause of cerebral hemodynamic disorders is not a history of nasal trauma, but difficulty in nasal breathing and reflex changes in the body caused by deformation of the nasal septum.

So, when studying patients with deformation of the nasal septum, it is necessary to take into account both local changes in the nasal cavity and the general effect of this pathology on the body, in particular, rheoencephalography indicators, which characterize the state of cerebral vessels, in particular the duration of the anacrotic phase of the REG curve and the magnitude of the dicrotic and diastolic indices, which in such a situation are the most informative. 


\section{DISCUSSION}

When correcting the deformity of the nasal septum in the cartilaginous part, the cartilage during the operation was maximally preserved, removing only the curved areas. In tuberous deformities, the cartilage was thinned, removing excess tissue and keeping the cartilage positioned in the sagittal plane drawn along the midline. If the cartilage was significantly deformed in a limited area in the form of a thorn or a small ridge, the part of the cartilage located outside the midline was removed.

In most cases, cartilage deviation was localized in the lower part of the nasal septum. In this case, only a part of the cartilage was removed, which deviated significantly from the midline. Since this deformity, as a rule, was combined with a significant deviation of the crest of the palatine process of the upper jaw, it was simultaneously thinned with preservation of the bone along the midline, which fundamentally differs from the known methods.

In some cases, it was possible to preserve the connection between the bone and cartilage, but in most cases it was necessary to mobilize the cartilage along the lower edge. To prevent possible re-deformation of the nasal septum in the late postoperative period, associated with the displacement of the lower portion of the quadrangular cartilage, after eliminating the deformation of the quadrangular cartilage, we fixed its lower portion to the ridge of the palatine process of the upper jaw using sutures. At the same time, on the concave side of the cartilage, parallel sections were applied to $2 / 3$ of its thickness, and on the convex side, mucoperichondria exfoliation was avoided if possible. It is the preservation of the perichondrium on the convex side that helps to align the cartilage. When mucoperichondria is detached from both sides, the straightening of the cartilage is not observed, and when mucoperichondria is detached only from the convex side, an even greater deformation of the cartilage is observed. The author argues that it is the perichondrium that plays a major role in the biomechanics of cartilage and contributes to its alignment.

\section{CONCLUSION}

Thus, when performing septoplasty in patients, it is advisable to use a tissue-preserving method of operations while preserving the skeleton of the nasal septum. After the elimination of the deformity of the nasal septum, when there was a displacement of the quadrangular cartilage, and its transfer to the median position, it is advisable to fix the cartilage to the bony part of the nasal septum along its lower edge, which contributes to its stabilization in the sagittal plane and allows to prevent the deviation of the cartilage from the median position to the postoperative one. period. The manufacture of cartilaginous plates to replace defects in the skeleton of the nasal septum is advisable to perform the proposed device, which significantly reduces the time and improves their quality.

\section{References}

1) Botirov, A. J., et al. "Clinical and morphological results of xenografts to use in myringoplasty." The International Tinnitus Journal 24.1 (2020): 1-6.

2) Djuraev, Jamolbek Abdukaxorovich, et al. "Results of Allergological and Immunological Research in Patients with Polipoid Rhinosinusitis." Asian Journal of Immunology (2020): 34-40.

3) Djuraev, Jamolbek Abdukhahharovich, Ulugbek Saidakramovich Khasanov, and Ulugbek Nuridinovich Vokhidov. "The prevalence of chronic inflammatory diseases of the nose and paranasal sinuses in patients with myocarditis." European Science Review 5-6 (2018): 147-149.

4) Normurodov, Bakhtoyor K., et al. "Prevalence and structure of purulent inflammatory diseases of the maxillofacial area." Central Asian Journal of Medicine 2020.1 (2020): 116-130.

5) Jumanov, Daulet Azadbek Ugli, et al. "International Journal of Biological and Pharmaceutical Sciences Archive." International Journal of Biological and Pharmaceutical Sciences Archive 1.1 (2021): 011-015.

6) Djuraev, J. A., et al. "Results of an immunogistochemical study in patients with polipoid rhinosinusitis." European Journal of Molecular \& Clinical Medicine 7.2 (2020): 2526-2541.

7) Khasanov, U. S., and J. A. Djuraev. "Morphological characteristics of chronic polypous rhinosinusitis." cutting edgescience (2020): 30.

8) Shaumarov, A. Z., et al. "Role of Hemostatic Agents in Simultaneous Surgical Interventions in the Nasal Cavity."

9) Kurbonov, Yokubjon Khamdamovich, Shukhrat Abdujalilovich Boymuradov, and Jamolbek Abdukakharovich Djuraev. "Purulent-Necrotic Diseases Of The Face: Aspects Of Diagnostics And Treatment." The American Journal of Medical Sciences and Pharmaceutical Research 3.01 (2021): 24-30.

10) Narmurotov, Bakhtiyar Karshievich, Shukhrat Abdujalilovich Boymuradov, and Jamolbek Abdukakhkhorovich Djuraev. "Comparative Characteristics Of Rheological Properties Of Blood In Combined Face Injuries Before And After Treatment." The American Journal of Medical Sciences and Pharmaceutical Research 3.01 (2021): 67-75. 
On The Features of Changes In Hearing And Cerebral Hemodynamics In Patients With Nasal Obstruction Curvature

11) VOHIDOV, Ulugbek Nuridinovich, et al. "Current issues of the treatment of chronic polypous rhinosinusitis." Journal of Biomedicine and Practice 2.5 (2020).

12) Kurbonov, Yokubjon Khamdamovich, Shukhrat Abdujalilovich Boymuradov, and Jamolbek Abdukakharovich Djuraev. "Overview Of Comprehensive Treatment Of Acute Purulent-Inflammatory Diseases Of The Face And Neck." The American Journal of Medical Sciences and Pharmaceutical Research 3.01 (2021): 15-23.

13) Nigmatov, Iftikhor Obidjonovich, et al. "Post-Traumatic Defects And Face Deformations: Features Of Diagnostics And Treatment." The American Journal of Medical Sciences and Pharmaceutical Research 3.01 (2021): 55-66.

14) Djuraev, J. A. "Improvement of comprehensive treatment vasomotor rhinitis."

15) Khasanov, U. S., U. N. Vokhidov, and J. A. Djuraev. "State of the nasal cavity in chronic inflammatory diseases of the nose and paranasal sinuses in patients with myocarditis." European science,(9 (41)).-2018 (2018).

16) Vohidov, U. N., and J. A. Djuraev. "ugli, Makhsitaliev, MI, \& Khamidjanov, s." (2020).

17) UN, Vokhidov, et al. "The local immunity in the tissues of various forms of nasal polyps." ALLERGY. Vol. 71.111 RIVER ST, HOBOKEN 07030-5774, NJ USA: WILEY-BLACKWELL, 2016.

18) Vohidov, U. N. "Djuraev JA ugli, Makhsitaliev, MI, \& Khamidjanov, s. O.(2020). Current issues of the treatment of chronic polypous rhinosinusitis." Journal of Biomedicine and Practice 2.5.

19) Makhsitaliev, Mukhammadbobur, et al. "The Functional State Of The Mucous Membrane Of The Nasal Cavity And Paranasal Sinuses After Radical And Minimally Invasive Surgical Interventions." The American Journal of Medical Sciences and Pharmaceutical Research 3.01 (2021): 31-40. 